Historic, Archive Document

Do not assume content reflects current scientific knowledge, policies, or practices. 



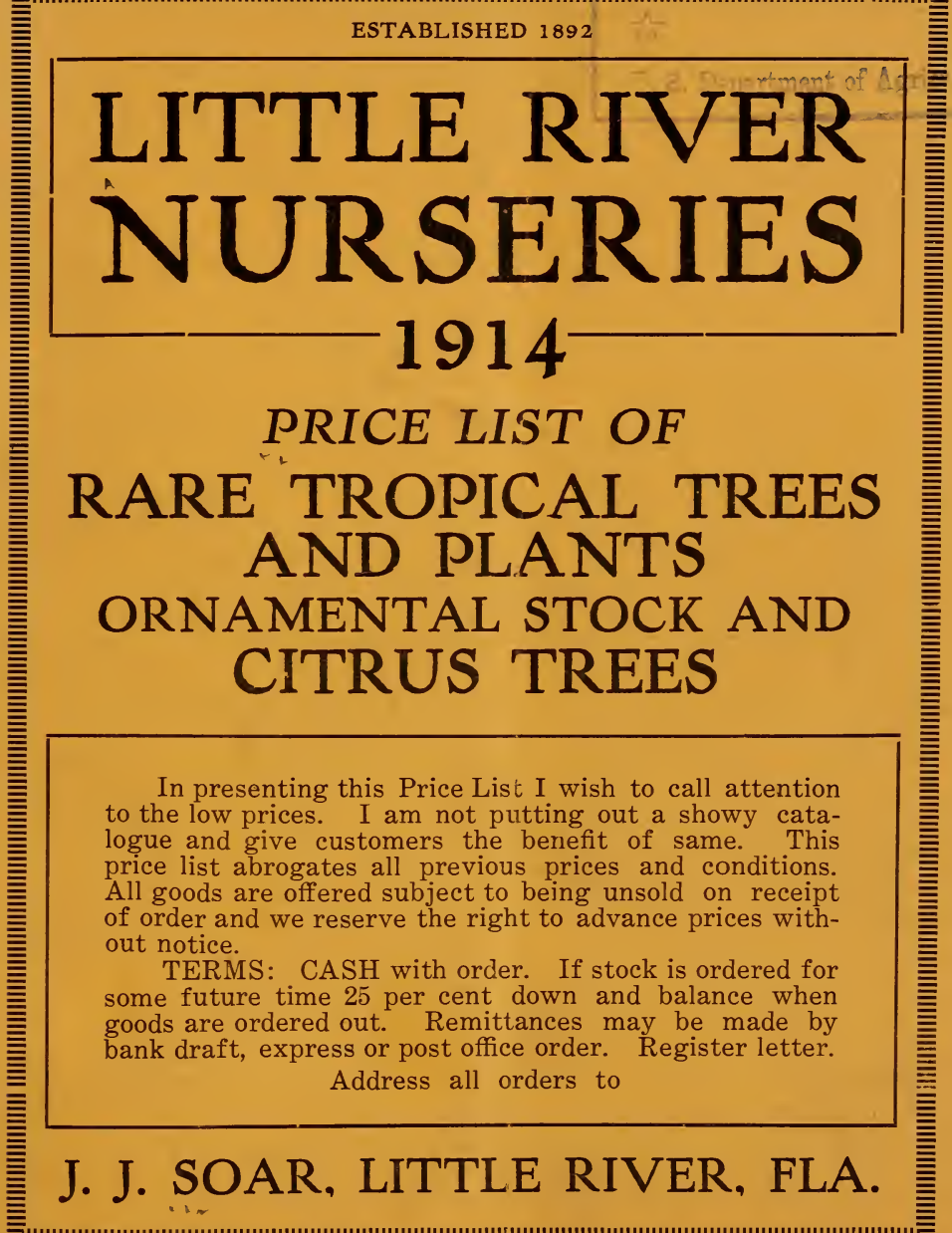

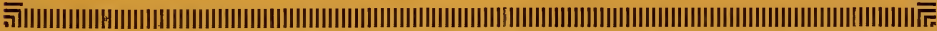




\section{Orange and Grapefruit Trees}

I have at the present sold close and have very few to offer, but will have trees to fill orders in June, especially in small sizes. Will have a few large size.

Oranges, Hart's Late or Tardiff, Jaffa, Homosassa, Dancy Tangerene,

King.

Grape Fruit. Florida Common, extra selected (Is the best Grape Fruit),

Marsh Seedless, Connor Prolific, Davis Seedless.

\begin{tabular}{|c|c|c|c|}
\hline ft. high straight trees & .45 & $\$ 4.00$ & $\$ 35.00$ \\
\hline $3 \mathrm{ft}$ high straight trees & .60 & 5.50 & 45.00 \\
\hline $4 \mathrm{ft}$. high, partly branched_---- & .80 & 7.00 & 60.00 \\
\hline \& $5 \mathrm{ft}$. high, stocky and branched tre & 1.00 & 9.50 & 90.00 \\
\hline
\end{tabular}

\section{Tropical Fruits}

Persea Americana (Gratissima) Avocado Pear. A valuable fruit used for salad. Selected seedlings, pot grown----

A few large size, from 3 to 8 feet, in tubs_--_--_---- .35 to 1.25

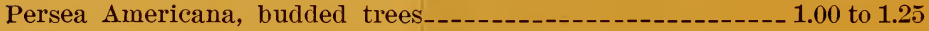

Persea Americana, Mexican seedlings, pot grown--------- $\quad .40$

Mangifera Indica. The Mango. A tropical fruit, especially

for South Florida. Pot grown seedlings

Mangifera Indica. Named sorts inarchedor budded trees-- 1.00 to 1.50 Achras Sapota (Sapota Zapotilla). The Sapodillo; 3-in. pots $\quad .20$

Achras Sapota, fine well grown 4-inch pots----------- $\quad .40$

Psidium Guava (Common Guara). Used for canning and jelly $\quad .15$

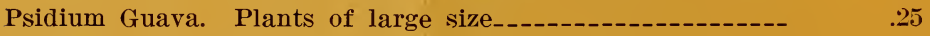

Psidium Cattleyanum. (The Cattley Guava); red, 3-inch pots $\quad .15$

Phidium Cattleyanum, large plants--------------------- $\quad .40$

Psidium Lucidum, yellow fruit, large plants_---_----------- $\quad .40$ 


\section{Tropical Fruits-Continued}

Monstera Deliciosa (Ceriman). An aroid plant with valuable

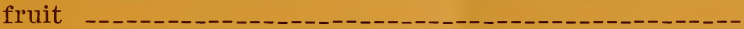

Monstera Deliciosa, large size plants in pots and tubs_----- 2.00 to 5.00 Eugenia Jambosa The Rose Apple Tree). Fruit rose scented;

makes a delicious candied fruit_-_-_-_-_-_-_-_-_-Eugenia Michelii (Surinam Cherry) --_-_-_-_-_-_--_-$.15 \& .25$ $.15 \& .25$

Mammea Americana (Mammee Apple). A large growing tree.

Fruit 4 or 5 inches in diameter. Pot grown-------..25, .50 \& 1.00 Carissa Arduina (Amatungula). A spiry shrub or small tree;

fruit scarlet, $1 \frac{1 / 2}{2}$ inches

Carica Papaya. Papaw or melon fruit

Musa Carendishii. The Dwarf Banana, the best and most profitable for South Florida; nice strong bulbs_-.---.-Musa Paradisiaca, rar Sapientum. (Orinoco Banand; large bulbs

Triphasia Trifoliata. Eriobotrya Japonica.

Winter and Spring-

Small red fruit; thorny, small tree-(Loquat, Japan Plum). Yellow fruit, sorts ; price on application.

Tamerindus Indica (Tamerand Tree). A large tree bearing fleshy pods. The pods broken in water make a delicious drink

Anona Muricata (Sour Sop). A large juicy fruit

Lucuma Rivicoa rar Angustifolia, Egg Fruit, or 'Ties

$.10 \& .15$

Ananassa Sativa. (The Pineapple). A few suckers of sereral sorts; prices on application.
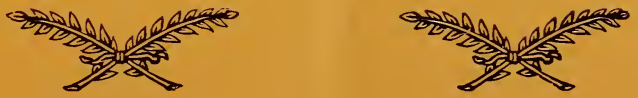

$.15 \& .25$ .15 to .25 .25 


\section{Palms}

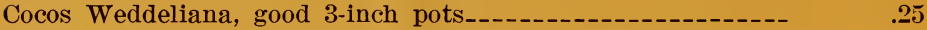

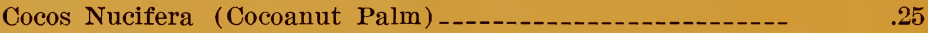

Cocos Nucifera (Cocoanut Palm), large size-------------- $\quad .50$

(If to be packed for shipment, 10 cents extra).

Cocos Flexuosa, 3-inch pots, $1 \mathrm{ft.}$

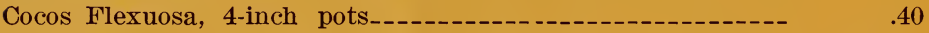

Cocos Flexuosa, 5 and 6-inch pots-----

Cycas Revoluta (Sago Palm). Price 10 to 15 cents per leaf. 25 to 5.00

Cycas Circinalis. Very rare palm; grows larger than Revo-

luta. Price from--

Kentia Forsteriana. Fine for house palms, 3-inch-------- $\quad .25$

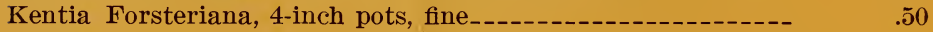

Kentia Forsteriana, good 6 and 7-inch pots; fine plants------ $\quad .50$

Hyophorbe Verschaceltii. Fine large plants in tubs, $\$ 1.00$, $\$ 2.00, \$ 4,00$ and $\$ 5.00$ each.

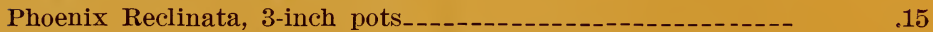

Phoenix Reclinata, 4-inch pots, 12 inches high-.---------- .25

Phoenix Reclinata, 4-inch pots, 18 inches--------------- $\quad .40$

Phoenix Reclinata, 6 and 6-inch pots----------------- $\quad 1.00$

Phoenix Roebelanii. A fine dwarf species; good house palm; small plants --.-- .25

Phoenix Roebelinii, 4-inch pot plants with character leaves-- $\quad .60$

Phoenix Roebelinii, 6-inch pots, fine plants-_-_-_-_--- 1.50

Phoenix Canariensis, 3-inch pots---_- 20

Phoenix Pumila, 4-inch pots, 12 inches high------------ $\quad .35$

(All the species of Phoenix do well in South Florida on high or low land).

Areca Lutescens. A splendid palm; grows in dense clumps; fine plants 


\section{Palms-Continued}

Area Lutescens, 4 -inch pots; fine-

Areca Lutescens, 6 and 7 -in. pots, $2 \frac{1}{2}$ to $3 \mathrm{ft}$., $\$ 2.00$ and $\$ 3.00$.

Areca Rubra (Dictyosperma-Rubra) 3-inch pots, 12 inches_-

Areca Rubra, 5-inch pots, 2 feet-_-_-_-_-_-_-_-_-_-_-_--.

Areca Rubra, large size, 10 and 12 -inch. $\$ 1.00, \$ 2.00$ and $\$ 3.00$.

Caryota Urens (Fish-Tail Palm) 3-inch pots_-.-_-_-_-_-_--

.50

Caryota Urens, large size, 7 -inch pots, 3 feet high.--_..----

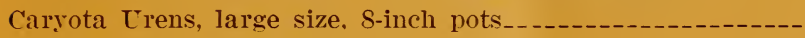

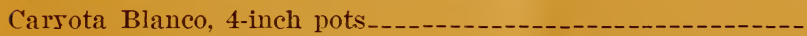

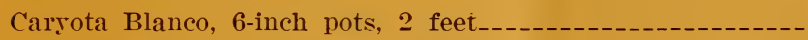

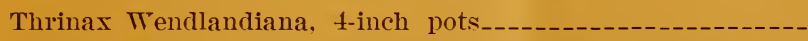

Thrinax Wendlandiana, large. $8,10,12,14,16,18$-inch pots $.25 \& .35$

and tubs. two to $10 \mathrm{ft}$. hi $\$ \mathrm{~h} . \$ 1.00 . \$ 2.00, \$ 3.00, \$ 5.00, \$ 7.00$.

Latania Borbonica (Liristona) 3-inch. 12 inches_-_-_-_-_-.-

4 -inch, fine plants-_-_-_-

5 and 6 -inch. .50 and $\$ 1.00$ each.

\$, 10 and 12-inch. $\$ 1.50$ to $\$ 3.00$ each.

Latania Glaucophylla. Rare palm, $\$ 1.25$ to $\$ 2.00$.

Sabal Megacarna, 3-inch pots $.10 \& .15$

Neowashingtonia Robusta, 3-inch pots_-_-_-_-_-_------ $\quad .20$

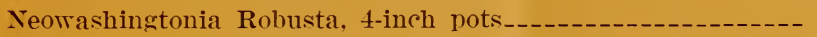

Neorrashingtonia Robusta, 5 and 6 -inch pots--_-_---_---- $.50 \& .60$

Neowashingtonia Robusta, $s, 10,12,14$-inch pots and tubs_-_1.00 to 2.00

This magnificent palm flourishes on rich, moist land.

By mulching and watering, does well on high land.

Roystonea Regia (Royal Palm). Small, from 2-inch pots--

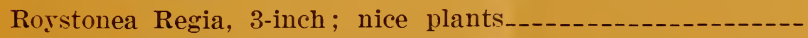

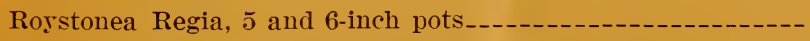

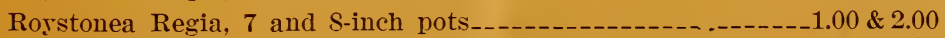

Pandanus Veitchii, 3-inch pots, 8 and 10 inches high--.--.-. .20 


\section{Palms-Continued}

Pandanus Veitchii, 4-inch, fine plants, well colored-----------

Pandanus Veitchii, large plants, .50 to $\$ 5.00$ each.

Pandanus Veitchii, price per $100,1,000$ or 10,000 on application.

Pandanus Baptistii and P. Sanderii are splendid for large

specimens. Price same as P. Veitchii.

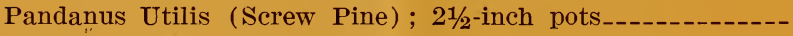

Pandanus Utilis, 3-inch, fine plants------------------

Pandanus Utilis, 5 and 6 -inch pots

Pandanus Utilis. Price per 100 and 1,000 on application.

Zamia Floridana, fine bulbs

\section{Bulbs and Bulbous Plants}

Crinum Floridanum. A small Crinum with short flower spikes, pure white flowers; very rare-----------------

Crinum Americanum. Fine blooming bulbs, $\$ 1.00$ per doz.--

Crinum Kirkii. A fine large bulb, sometimes 5 or 6 inches in

diameter. Flowers striped white and pink-_-_-_-_----

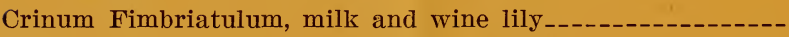

Hymenocallis Caribaeum (Pancratum) Spider Lily, per doz.

$\$ 1.00$-----_-

Amarylis Equestris. Flowers bright red----_-----------

Canna Flaccida. Flowers yellow. Per dozen, .50_------

Canna Indica, Sp. Red flowers, wine colored foliage, per doz. .50

Canna Italia. Flowers red and yellow. One of the very best. Dozen, .80

Canna Austria. Flowers yellow. Per dozen, .59---_------- 


\section{Bulbs and Bulbous Plants-Continued}

Lilium Harrisii. Bermuda Easter Lily. Dry bulbs September to December---15

Lilium Giganteum. Large flowered sort.-_-_-_-_-_-_--

Narcissus Orientalis (Chinese Sacred Lily) -------------- $\quad .10$

Richardia Africana. (Calla Lily). Dry bulbs----------- $\quad .10$

Caladium Esculentum. Very large leares. Strong bulbs_--- .10\&.25

Caladium Bulbosum. Fancy leared caladium--_----------

Alocasia Microrhiza. Very large leares. Per dozen, $\$ 1.00$

and $\$ 2.00$

Alocasia Microrhiza. A few very large plants_-_-_-_-_-_-- 1.00 \& 2.00

Hedychium Coronarum (Ginger Lily). Flowers white------ 25

Alpinia Nutans. Shell lily. Nice plants-_-_-_-_-_----- 25

Curcuma Petiolata (Queen Lily). A fine summer grotrer;

fine tubers -

Zanthosoma, Sp. Leares resemble Alocasia and Caladiums tu-

bers; edible, and the plants make a tropical effect rery

quick

\section{Air Plants}

Tillandsia Ctriculata. The Pine Apple Air Plant; grows large $.10 \& .25$

Tillandsia Fasciculata. Air plant with large brilliant crimson bracts (Syn. T. Bracteata) --_-_-

Catopsis Nutans (C. Berteroniana). A pretty air plant (Test Indies )

Guzmannia Monostachya. Test Indian air plant. Flowers small, white, borne on brilliant crimson bracts---------$.10 \& .25$ .25 .50

Guzmannia Varigata. Like the abore, but has white stripes
in the green leares

Guzmannia Varigata. Like the abore, but has white stripes
in the green leares.--

Hohenbergia Penduliflora. A large plant, resembles an Aechmea, but larger, leares haring blunt ends. A splendid plant of tropical effect

$.50 \& 1.00$ 


\section{Orchids}

Cyrtopodium Punctatum. A fine large orchid with immense flower spikes, yellow, dark red and brown flowers. Bulbs 10 to 15 inches long, from $1 / 2$ to 1 inch thick. I have had specimen plants that would weigh 75 pounds. Price, each_\$ .50 to 5.00 Oncidium Luridum. Flower spikes 3 to 8 feet long; flowers

yellow, with dark red or brown spots. Price, each-_-_-- .50 to 3.00 Epidendrum Tampense, butterfly orchid. Nice clumps_------- .15 to .25

Epidendrum Cochleatum, chocolate colored flowers--------- $\quad .15$

Epidendrum Nocternum, white flowers-_-_-_---_------ $\quad .15$

Vanilla Planifolia. Vanilla plant, from which the extract is

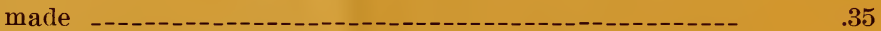

Vanilla Eggersi, wild vanilla. An odd vine; climbs on wood or stone. Plants --_-_-_- $15 \& .25$

Cattleya Trianae. Flowers large purple; one of the finest

orchids in cultivation. Price from-_-_--- 1.00 to 5.00

Cattleya Scheaderaea. Flowers creamy white with yellow

and purple. One of the fine sorts-_- 1.00 to 5.00

Dendrobium Noble. Flowers light purple. Bulbs 1 to 2 feet

long. One of the standard good orchids_--_-_---- 1.00 to 5.00

\section{Cactus and Agaves}

Cereus Triangularis. One of the night-blooming Vereus; large three-sided, flowers large_-_-_-_-_-_-_. $10 \& .25$ Cereus Grandiflorus. Night-blooming Cereus. Flowers white;

8 inches across. Will climb wood or stone--_-_-_--- $.10 \& .25$ Opuntia Ficus Indica (Fig Cactus) ----_-

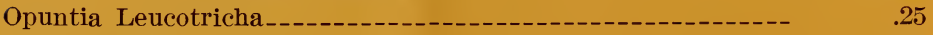
Opuntia Tuna - - 


\section{Cactus and Agavas-Continued}

Pedilanthus Tithymaloides (Bird Cactus)

.5 to .25

Furcraea Tuberosa. An agave-like plant, one of the best

known fibre plants --.---

Yucca Aloifolia (Spanish Bayonet). Crowns for planting--.-

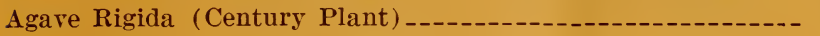

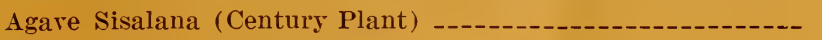

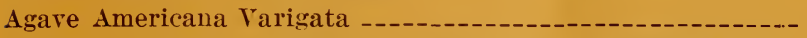

Pereskia Aculeata (Barbados Gooseberry). A ciimbing cactus

Aloe. Two sorts, fine plants_-_-_-_-_-

.10 to .25

.10 to .25

.10 to .25

Bryophyllum Calycinum. An odd succulent plant------------

Epiphyllum Truncatum (Crab's Craw Cactus) A grand house

plant, blooming in mid-winter bright pink-.----------.-

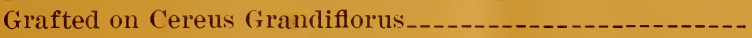

.10 to .25

.25

$.10 \& .25$

$.10 \& .25$

.10

$.15, .25$

.35 to .50

\section{Evergreens or Conifers}

Araucaria Excelsa (Norfolk Island Pine). A tropical pine.

4-inch pots 8 to 10 inches high, 2 and 3 tiers-_-_-_.-- $\$ .75$

5-inch, pots 12 to 14 inches high, 2 to 4 tiers---_------ 1.00

8 to 12 -inch pots, 24 to 30 inches high---_--------- 2.25

In large tubs and large barrels, 30 and 40 -inch

$4,6,8,12$ and 16 feet high, each-_-_._-_-_\$ $\$ .00, \$ 6.00, \$ 8.00, \$ 15.00$

Araucaria Robusta Compicta, 2 to 3 feet---_-_-_------- 2.50 to 3.50

Araucaria Glauca, to to 3 feet--_-_-_---_--------- 2.00 to 3.00

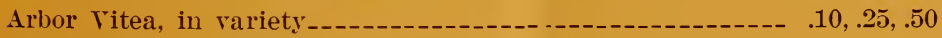

Casuarina Equistifolia (Australian Pine). Used for wind

breaks and street trees; 3 -in pots, .15 ea.; $\$ 10.00$ per 100 .
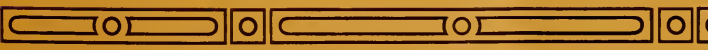


\section{Miscellaneous Plants}

Deiffenbachia Nobilis, green leaves blotched with creamy

white; needs heat and moisture; 3-inch pots.

Dracaena Terminalis, fine, 3-inch pots

$\$ 35$

.25

Dracaena Terminalis, 4 and 6 -inch pots

$.50 \& 1.00$

Dracaena Goldieana, a fine sort when well grown

1.00

Dracaena Godseffiana, nicely colored, 4-inch pots---.--------

Ravenala Madagascariensis, the Traveler's Tree. Has a trunk

like a palm and leaves resemble the banana. A few large

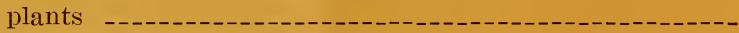

Sanseviera Zeylanica. Nice plants, .10 and .25; large clumps

in boxes

Saiseviera Guineesis. Same price as abore.

Pothos Aurea. An aroid plant, large leaves, green and yel-

low ; climbing on wood or stone. .10, .25, .50, $\$ 1.00$.

Poinsettia Pulcherrima. Well known Poinsetta, with scarlet

bracts from November to March, .10, $\$ 8.00$ per 100 .

Larger plants, .25, .50 and .75.

Cestrum Parquii. Night blooming, very strong scented at

night -----_-

Cestrum Diurnum. Day bloomer --

.10 to .25

.10 to .25

Codiaeum Variegatum. Croton. About 30 varieties, 3 inch

pots, 8 inches high, $.10, \$ 1.00$ per $10 ; \$ 9.00$ per 100 .

10 to 12 inches high, .15 and $.20 ; \$ 1.40$ and $\$ 1.80$ per 10 .

4,5 and 6 -inch pots, .25, .40 and .65 each.

Tecoma Stans. Yellow Elder. Has large cluster of yellow

flowers. A splendid plant for planting in open ground.

Ardisia Pickeringii. A fine dark green foliage. Blooms in fall

and winter

.10 to .25

disia Crenulata. Flowering shrub, berries white and turns

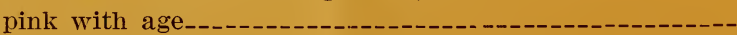

Grevillea Robusta, Australian Oak. Good shade tree---------

$.10 \& .25$

$.15 \& .25$

$.10 \& .25$ 


\section{Miscellaneous Plants-Continued}

Coleous. In rariety, $.5, .45$ per $10 ; \$ 3.50$ per 100 .

Sanchezia Nobilis. A tender foliage plant. Leaves green striped from the mid-rib to the margin with yellow--.---

Tradescantia Erecta (discolor). Leares green on top, purple on the under surface-

.10 to .25

.10 to .25

Tradescantia Zebrina. The Wandering Jew. A cre 'ping plant.

Cuttings, .01; .10 per dozen; .75 per $\$ 1.00$.

Acalypha Tricolor. The bright foliage plant used for hedges.

Fine young plants, $.5 ; .40$ per $10 ; \$ 3.00$ per 100 .

8 to 10 inches high, $.10 ; .80$ per $10 ; \$ 6.00$ per 100 .

2 feet high, .25; a few very large plants on application.

Acalypha Marginata. Same price as abore.

Acalypha Triumphans. Very large dark red leaves with light red blotches, .05 each; .40 per $10 ; \$ 3.00$ per 100 .

8 to 10 inches high, $.10, .80$ per $10 ; \$ 7.00$ per 100 .

Acalypha Miltoniana. Fine cut foliage. Price same as above. Acalypha Sp. A sport from the above. Green leaves with

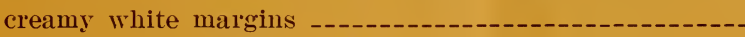

Achyranthus. A well known foliage plant, in rariety.--.-.50 and $\$ 1.00$ per dozen.

Eranthemum Pulchellum. Flowers dark blue, produced through winter. Plants._-_._.-...-

Plumiera. Flowers white -.--_-_$.10 \& .25$ $.5 \& .10$

Achania Malvarescus. Flowers red blooms continually--.-Jacobinia Coccinea. Scarlet flowers continually--------Durantia Plumeria. Flower's in recemes, lilac in color, fol-

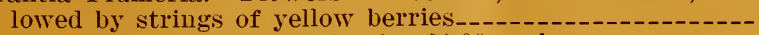
A few in large boxes and tubs, $\$ 1.00$ each.

Hamelia Patens. A native erergreen shrub; flowers of an orange red --

.10 to .25 .50 .10 to .25 .10 to .25

.10 to .25 .10 to .50

Tabernaemontana Coronaria. Large doubled pure white tlowers, resembling a Cape Jassamine; grows well here, while the Gardena does not

.15 to .35 


\section{Miscellaneous Plants-Continued}

Jasminum Sambac, Arabian Jessamine. Flowers white-...-Jasminum Sambac, Grand Duke Jassamine. Flowers large, white and scented, .20 to $.30 \& .50$.

Ixora Coccinea. A dwarf shrub with showy orange yellow flowers

Plumbago Capensis. Flowers are sky-blue; blooms constantly

Russellia Juncea. Fountain Plant. Has a wiry mass of green with scarlet tubular flowers

Euphorbia Tiriculli. Fine plants, .25; large, .50.

Euphorbia Havensis. Large three-angled stems

Cyperus Papyrus. The Moses Bullrush

Bauhinia Alba. Mountain Ehony. A small shade tree; has

white flowers in Spring

Bauhinia Purpurea. A very showy flowering tree. The flow-

ers are purple, resembling that of an orchid.-......Cordia Sebestina. Small shade tree; orange red flowers---Aralia Guilfoylei. Foliage grten and creamy white, .10, .25, $.50, \$ 1.00, \$ 2.00$ each.

Aralia Filicifolia. Fern-like foliage, $.10, .25, .50$, and $\$ 1.00$ ea. Chrysophyllum Monopyrenum. Satin leaf tree, .25, .50, $\$ 1$ ea. Chrysobalanus Icaco. The cocoa plum; small tree, dark green

foliage, with a small edible fruit_-_-_-_-_-_.--_-_-

Begonia Ricinifolia. Fine plants

Thunbergia Erecta. Light blue flowers

Phyllanthus Rosea Picta

Phyllanthus Latifolea. Flat foliage; small plants, .20, .35, .50 and $\$ 1.00$ each.

Rabdadenia Paladosa (Echites P.) A climber; grows on moist

soil. Flowers creamy white with a yellow throat.--_-_-Albezzia Lebbek. A large shade tree with pinate leaves.-.Terminalia Catappa. Tropical Almond. A large shade tree;

4-inch pot plants -

Erythrina Carnea. Shade tree with crimson flowers in early

Spring

Erythrina Arborea. A large growing native sort

.25 to .50

.25 to .50

.25 .25

$.15 \& . .5$

$.25 \& .50$ $10, .15, .25$ $.15 \& .25$ $.5 \& .10$

Mesantica Triandria. A good shade tree, very rare. 